\title{
Articles
}

\section{The Protection of Human Dignity in Hungarian Media Regulation}

\author{
By András Koltay*
}

\section{A. About the Legal Concept of Human Dignity}

Human existence and dignity, just like human unity itself, are not actually rights. The essence of humanity, as regards the law, is inaccessible. Because of this, human life and dignity are included in the catalogue of human rights and in modern constitutions as the sources of rights, as inviolable values beyond the law. The law must guarantee that these inviolable values are respected and protected. ${ }^{1}$

Under the interpretation of the Alkotmánybiróság (Hungarian Constitutional Court; hereinafter referred to as Constitutional Court), the right to human dignity is the "mother right" of all other individual rights and, thus, the source of all other specific individual rights (Decision No. $8 / 1990$ (IV. 23.) $A B^{2}$ ). Human dignity is a paramount value, which is unapproachable and inaccessible for the law. The law cannot define human dignity, cannot summarize all of its sub-elements, and cannot grasp its essence in a technical sense; however, the law can protect human dignity even in the absence of a detailed definition.

The background of the Constitutional Court's philosophy in describing the content of the right consists of the ideology of Christian natural law and Kantian moral philosophy. Behind the Constitutional Court's monistic view of man and the "indivisibility doctrine" lies the concept of the Christian world view, according to which man is the image of God, and man's personal spiritual soul is the unique work of God's creation.

Human dignity is the principal constitutional guiding principle for the creation and application of all laws and the actual foundation of the system of constitutional fundamental rights, values and obligations. [Decision No. 37/2011 (V. 10) AB].

\footnotetext{
* Associate Professor at Pázmány Péter Catholic University, Budapest, Hungary.

E-mail: koltay.andras@jak.ppke.hu.

${ }^{1}$ Decision No. 23/1990 (X. 31) AB of the Constitutional Court, Concurring opinions of Tamás Lábady and Ödön Tersztyánszky.

2 The first number of the decisions' notation stands for its line number, the second for the year in which it was brought. In brackets, the month and the day of its publication appear. "AB" is the abbreviation for the Constitutional Court.
} 
As such, the right to human dignity, together with the right to life, is the absolute limit of the restriction of all other fundamental rights. It is the untouchable essence within the essential content. The Constitutional Court connected the concept of essential content with the concept of human dignity, creating an absolute limit as regards the constitutional scrutiny of the restriction of fundamental rights. [Decision No. 23/1990 (X. 31) AB]. Connecting the right to human dignity and the essential contents of fundamental rights made it clear that the Constitutional Court regards the system of fundamental rights as a value system. Its starting point was the theoretical consideration that the Constitution's system of fundamental rights is not the aggregation of sporadic or isolated rights, but it is an integral whole, the foundation and source of which is the right to human dignity. Ultimately, every right can be traced back to and other rights can be deduced from human dignity. In other words, fundamental rights are interwoven with and presuppose one another, but it does not matter which fundamental right is at issue; there is an absolute limit to their restriction. ${ }^{3}$

One of the functions of the right to human dignity is to guarantee autonomy, as human dignity "is the seed of individual self-determination free from any other person's will, which ensures that . . . that the person can remain an individual and does not become an instrument or object." [Decision No. 8/1990 (IV. 23) AB]. The other function of the right is to guarantee equality by ensuring that everybody has an equal right to dignity. According to the Constitutional Court's interpretation, it also follows from the mother right nature that human dignity is:

[S] uch a subsidiary right that both the Constitutional Court and other courts may invoke it for the protection of the individual's autonomy if none of the concrete, specific fundamental rights can be applied to the specific facts of the given case. [Decision No. 8/1990 (IV. 23) AB]

Human dignity is only unrestrictable in connection and forming a whole with the right to life (see the issues of the death penalty, abortion, and euthanasia). If it is separated from the right to life, the individual partial licenses deriving from it can already be restricted. Reputation, integrity and human dignity are personal rights which may be separated but which are closely connected with each other. Reputation and integrity (or honor) protect the social value judgment formed of a person. Article 78 of the Hungarian Civil Code (Act IV of 1959) protects against defamation and prohibits the statement and dissemination of false facts or the misrepresentation of true facts that would be injurious to another person. The Civil Code also protects the right to integrity (or honor) and includes the right

3 Zsolt Balogh, Alapjogi tesztek az Alkotmánybíróság gyakorlatában (Fundamental Rights Tests in the Jurisprudence of the Constitutional Court), in A MEGTALÁLT ALKOTMÁNY? A MAGYAR ALAPJOGI BíRÁSKODÁS ELSŐ KILENC ÉVE (Constitution Found? The First Nine Years of Hungarian Fundamental Rights Jurisprudence) 124 (Gábor Halmai ed., 2000) 
to human dignity (Article 76), but civil court jurisprudence does not attribute independent meaning to the latter; for the most part, it regards integrity identical with human dignity.

Pursuant to Article 179 of the Hungarian Criminal Code (Act IV of 1978), the publication of any facts capable of undermining integrity (or honor) may substantiate the commission of the offence of libel, and Article 180 prohibits -in addition to certain other conditions - the use of statements capable of undermining integrity (the offence of slander). The Civil Code does not expressly cover human dignity, but for the most part, here also, the jurisprudence views it as identical to the right to integrity. Human dignity thus has no independent meaning or content, either in civil or criminal law.

\section{B. Protection of Human Dignity and Freedom of the Press in Europe}

The protection of human dignity is not merely one of the foundations of European media regulation but also one of the bases of the common European legal order. ${ }^{4}$ According to McCrudden, the concept of human dignity differs from legal system to legal system, and sometimes it can mean different things even within the same legal system; nevertheless, human dignity has a special significance in ruling on cases concerning human rights. ${ }^{5}$

The protection of human dignity in television broadcasting is prescribed by the television broadcasting convention of the Council of Europe: "[a]ll items of programme services, as concerns their presentation and content, shall respect the dignity of the human being and the fundamental rights of others. ${ }^{\prime \prime}$ In addition to this, the protection of human dignity in the common European media regulation appears primarily in the form of the prohibition of hate speech in audiovisual media services. ${ }^{7}$ With respect to audiovisual services and the Internet, the European Parliament and the Council have formulated a recommendation in order to protect human dignity more effectively. ${ }^{8}$

\footnotetext{
${ }^{4}$ Perry Keller, European and International Media law. Liberal Democracy, Trade and the New Media 135-139 (2011).

${ }^{5}$ Christopher McCrudden, Human Dignity and Judicial Interpretation of Human Rights, 19 EUR. J. OF INT'L L. 655 (2008).

${ }^{6}$ The European Convention on Transfrontier Television, adopted on 5 May 1989, was promulgated in Hungary by Article 7(1) of Act XLIX of 1998.

7 Directive 2010/13/EU on audiovisual media services, Art. 6. See more on this in Tarlach MCGonAGLE, Safeguarding Human Dignity in the European Audiovisual Sector, 6 IRIS PLUS, LEGAL OBSERVATIONS OF THE EUROPEAN AUDIOVISUAL OBSERVATORY (2007).

${ }^{8}$ Recommendation No. 2006/952/EC of the European Parliament and of the Council of 20 December 2006 on the protection of minors and human dignity and on the right of reply in relation to the competitiveness of the European audiovisual and on-line information services industry.
} 
The protection of human dignity is part of the media regulations of a number of European countries (France, Luxembourg, Italy, Portugal, Slovakia, Slovenia, Cyprus, Romania, the Czech Republic, Greece and Spain). It is characteristic of these regulations that they include the protection of human dignity as the alternative to the violation of reputation and integrity, or sometimes they are included in the regulations as provisions in addition to the reputation and integrity causes of action. They chose different approaches than in the Hungarian regulation, which regulates the issue of personality violations committed in the media as part of the general personality protection regime (Civil and Criminal Code), and it does not incorporate the protection of personal rights in the media regulations. This also means that, in these states, the media authorities may initiate proceedings in cases of violations of dignity (reputation and integrity). ${ }^{9}$ Another solution-which is also used in Hungarian media regulation, in Article 14(2) of the Press Freedom $\mathrm{Act}^{10}$-is when the law prohibits specific conduct violating human dignity. ${ }^{11}$

The regulation of the European states shows a colorful picture, and in the light of these laws-as well as being mindful of the debate surrounding the Hungarian media regulations-it can be stated that the Hungarian regulations and jurisprudence are special, and its unique solution may carry European level lessons.

\section{Protection of Human Dignity in Hungarian Media Regulations}

Article 3(2) of the Radio and Television Broadcasting Act, in effect from 1996 until 1 January 2011, stated that "Broadcasters are obligated to respect the constitutional order of the Republic of Hungary, and their activities shall not violate human rights." The rule applied exclusively to "broadcasters," and therefore (according to the definition of the

\footnotetext{
${ }^{9}$ This is how the French (Article 1 of the Freedom of Communication Act no. 86-1067), Luxembourgish (Article 1(2)(c) of act of 27 July 1991 on Electronic Media), Italian (Legislative Decree 31 July 2005, no. 177; Articles 3-4 of the Audiovisual Media and Radio Services Code), Portuguese (Law no. 27/2007 of July 30; Article 27 of the Television and On-Demand Audiovisual Services Law, Law no. 54/2010 of December 24; Articles 30 and 32 of the Radio Law), Slovakian (Article 19 of Act no. 308/2000 Coll. on Broadcasting and Retransmission), Slovenian (Article 6 of Media Act no 35/2001), Cypriot (Article 33(1) of the Radio and Television Stations Law of 1998) and Romanian (Law no. 504/July 11th, 2002; Article 9 of the Audiovisual Law) law regulate the issue with respect to media services and the Italian (Id.) and Slovenian (Id.) with respect to press products. (We use the title of foreign laws and regulations in English in every case.)

${ }^{10}$ Act CIV of 2010 on the Freedom of the Press and the Fundamental Rules of Media Content.

${ }^{11}$ Similarly to their Hungarian counterpart, the Czech (Article 32 of Act no. 231/2001 Coll., on the operation of radio and television broadcasting) and Portuguese (Law No. 1/99; Journalist Statute) regulations prohibit people being portrayed in vulnerable situations, and the latter also prohibits such depictions of children that violate their dignity (Id., Article 14). The violation of human dignity is prohibited in advertisements pursuant to the Czech (Article 2 of Act no. 40/1995 Coll., on the regulation of advertising), Greek (Article 3 of Law 2328/1995 "Legal regime of private television and local radio broadcasters, regulation of relevant market and other provisions") and Spanish (Article 57 General Audiovisual Law 7/2010) media regulations.
} 
currently effective law) to linear audiovisual and radio media services, and the law did not specify the fundamental right of human dignity.

The Constitutional Court considered the constitutionality of the protection of human rights (and within those, human dignity) in Decision No. 46/2007 (VI. 27) AB under the media regulations and held that

[I]f a broadcaster violates an individual right, the aggrieved person may decide whether to enforce their individual rights against the broadcaster having committed the violation, for example, by filing a court action. In addition to judicial action, Articles 112(1) and 136(1) of the Media Act [Radio and Television Broadcasting Act] provides for administrative remedies. The Országos Rádió és Televízió Testület ${ }^{12}$ ( National Radio and Television Commission; hereinafter referred to as "NRTC")-proceeding pursuant to Article 3(1) of the Media Act [Radio and Television Broadcasting Act]-does not decide on the violation of the rights of individual legal entities in these administrative proceedings. Article $3(1)$ of the Media Act [Radio and Television Broadcasting Act] is a provision of principle. Accordingly, during the administrative proceedings the NRTC is entitled to establish whether the broadcaster carries out its activities while respecting human rights, and whether the subject-matter, nature and perspective of its individual programmes violate fundamental values embodied in human rights.

The expression "fundamental values manifesting in human rights" in the Constitutional Court's decision may be interpreted in more than one way. It is not clear if, based on this, any values (basis) standing behind any human rights may provide a reason for administrative proceedings, and it is unclarified what we regard as values standing behind human rights and if these could be included in the judicial practice. It is surmised that the text quoted wished to indicate that the task for the media regulations is to safeguard the institution of human rights, in other words, it protects an institution indispensably important for society and not the person that suffered actual injuries as a result of the violation of human rights (see more in D. I.).

With respect to the right to self-determination, the Constitutional Court in this decision also stated that:

[A]n important element-among others-is the right of the person to enforce their subjective rights covered by the claim before various state authorities, as such including the courts as well. However, the right to selfdetermination also includes-as a general right to act-the right to refrain from enforcing claims or to non-action. Since this right is intended to protect

${ }^{12}$ Former Hungarian media authority (1996-2010). 
the autonomy of the individual, in general everyone is free to decide whether to enforce claims by way of the administrative proceedings available under the Constitution for the protection of rights and lawful interests, or to refrain from doing so. [Decision No. 1/1994 (I. 7) AB]

The right to self-determination therefore also covers the right to refrain from resorting to court action in the event of violation of one's rights, or refrain from enforcing one's rights in any other way. "If a broadcaster violates an individual right, the aggrieved person may decide whether to enforce their individual rights against the broadcaster which committed the violation."

Based on the decision of the Constitutional Court, it can thus be established that, in general, there is a constitutional opportunity for the protection of human dignity in the media regulations, but in the course of these proceedings it can only make a finding of the fact of the violation of a fundamental right by 'anonymising' it. (See the interpretation of this issue below.)

The material scope of the Press Freedom Act, which became effective on 1 January 2011, extends to on-demand media services, as well as print and online press products too. In addition to the material scope, the content of the relevant provisions has also changed substantially. The original text of Article 14 provided that: “(1) The media content provider shall, in the media content published by it and while preparing such media content, respect human dignity. (2) No wanton, gratuitous and offensive presentation of persons in humiliating, exposed or defenseless situations shall be allowed in the media content." Moreover, Article 16 said that "Media content providers shall respect the constitutional order and, in the course of their activities, they shall not violate human rights." Similarly to the earlier regulations, the text included the protection of the constitutional order and human rights, but the protection of human dignity was included in a separate statement of facts and, within that, another special statement of facts provided for a specific instance of the violation of human dignity (in the protection of persons in humiliating, exposed or defenseless situations).

It was an important change in the regulation that became effective in 2011 that dignity violations committed in the course of the production of programs also became prohibited. (The courts, in the course of their review and taking into account the earlier regulations, usually repealed the media authority decisions rendered in connection with this.)

The Press Freedom Act in its original form thus made it possible to bring an action in cases of the violation of dignity taking place in the course of the production of programs. In the case of such programs, where its participants are 'deprived' by contract-with their consent but under dubious circumstances-from the possibility of future enforcement of rights and legal remedies, or with regard to whom-also by contract-the possibility of preventing the recorded program from being broadcast (even if the broadcast is clearly 
injurious with respect to the contracting party, and the withdrawal of the consent to broadcast would not cause disproportionate damage to the broadcaster) is excluded, the media authority now may initiate proceedings. The authority did not take advantage of this regulatory instrument and, as the result of the amendment of the law, as of 19 June 2012, this provision was deleted from the text of the statute. The December 2011 Decision No. 165/2011 (XII. 20) of the Constitutional Court found the application of human dignity protection contained in the Press Freedom Act to press products to be unconstitutional and remedied the constitutional violation with the pro futuro repeal of the material scope of the statute.

The Constitutional Court continues to consider the general protection of human dignity in connection with media services to be constitutional. The principal reason for this is the media effect theory, which appeared several times before in the jurisprudence of the Constitutional Court. In the decision the tribunal confirmed its previous position according to which

in the case of audiovisual media, which have a special influence on the thinking of people and social processes, to guarantee such special action by the authority is a necessary and proportionate restriction. . . . This administrative proceeding, which is guaranteed for the sake of the viewers and listeners, is considered a necessary and proportionate intervention because of their especially strong influence on the audience. However, in the case of print and on-line media, the influence of which is different, the option for this kind of action-in this form generally extending to human rights-is considered a disproportionate restriction. (Statement of reasons, paragraph IV. 2.2.2.)

It should be noted that the media effect theory is disputed by many, and it can be indeed argued that, in today's convergent media world, television and radio's sharp distinction from the press cannot be justified in the regulation. However, in the light of media consumption statistics, these two types of services are the most influential today. The Press Freedom Act is based on the concept that certain content requirements can be prescribed to all media outlets, and in its opinion the Constitutional Court finds this approach constitutional with respect to hate speech, the protection of constitutional order and minors, as well as advertising rules. While the tribunal accepted the argument, according to which media regulation protects the public interest and not the individual rights of the aggrieved person, with respect to the press, it finds the media effect theory, as well as the availability of civil and criminal proceedings protecting individual rights sufficient to declare constitutional violation. This is without a doubt a coherent argument; however, the determination of its validity depends on the acceptance of the media effect theory (without precise data, the application of the effect theory is primarily the acceptance of a hypothesis on the part of the Constitutional Court). 
In the reasoning of the decision, the Constitutional Court states that "it is justified that the authority-within the scope concerning the institutional content of these rights - . . in the interest of the community, has the means to take action against the offender." (Paragraph IV. 2. 2. 2.) From this, compared with the 2007 Constitutional Court decision, the need for the separation of the branches of law safeguarding individual rights and media regulation is more clearly distinguishable.

The decision also provides that human dignity may be protected with respect to any media content, thus, given certain conditions, it can be the limitation of the freedom of the press with respect to press products, too, if it appears in the regulation not in a general wording but as a concrete statement of facts. It follows from this that the provision under Article 14(2) of the Press Freedom Act on persons in humiliating, exposed or defenseless situations is constitutional with respect to press products too. According to the Constitutional Court's reasoning:

In contrast, Article 14(2) of the Press Freedom Act sets forth such a special cause of statement of facts, which enables media authority actions sufficiently narrow in scope and based on a particularly compelling public interest. The provision regulating treatment of persons in humiliating, exposed or defenseless situations-in addition to indicating the absence or limitation of their qualification for personal rights protection-covers those instances of human rights violations which could seriously compromise the prevalence of the substance of the institution of human dignity. Legal protection by the authority within this realm therefore means proportionate restriction in the case of all media channels. (Reasoning, paragraph IV. 2.2.2.)

The tribunal made it clear that this case-in addition to the limited status of the right to self-determination-justifies action because it may also seriously compromise "the substance of the institution of human dignity" - thus, according to the Constitutional Court, the objective and justification of the regulation is the protection of the institution of human dignity-more precisely, the protection of its "institutional substance" - and not the protection of individual rights. It can be concluded from this part of the reasoning that the Constitutional Court would accept as constitutional other specific fact patterns undeniably violating human dignity if they were sufficiently narrow in scope and based on a particularly compelling public interest, and the circumstances pertain to a case where the qualification for personal rights protection is absent or limited.

In any case, the legislature, which was in a legislative dilemma, chose the simplest solution: according to the text effective as of June 19, 2012 of Article 14(1) of the Press Freedom Act, "[m]edia service providers, in media content they publish, shall respect human dignity." In other words, the text applies only to (linear and on-demand) media services and only to the content that appears on the screen or is audible in the ether. Furthermore, the legislature has deleted the protection of "human rights" from Article 16, thus closing 
an old, unresolved dispute (originating from the interpretation problems of the text of the 1996 Media Act) that surrounded the question as to which human rights should be protected by the media regulations. Pursuant to the new wording, this can only be a right specified in the Press Freedom Act (such as human dignity).

\section{Justification of the protection of human dignity under the media regulations}

\section{Institutional Protection-An Individual Right}

We have to take a short detour to the foundations of the "state institutional protection obligation" developed by the Constitutional Court. According to the principles laid down in Decision No. 64/1991. (XII. 17.) AB of the CC, the human rights protection obligation of the state has a dual nature: on the one hand, it protects the human rights guaranteed to individuals (legal entities), and on the other hand, in certain cases-and with respect to certain human rights -it has to provide for the conditions necessary for the prevalence of human rights (institutional protection). The institutional protection of a certain human right may be the justification of the restriction of another. With respect to the freedom of opinion, for example, based on Decision No. 30/1992. (V. 26.) AB of the CC, the state is required not only to guarantee the freedom of the expression of opinion to its citizens but it also has to ensure the appropriate functioning of democratic public opinion. Decision No. 46/2007. (VI. 27.) AB and Decision No. 165/2011. (XII. 20.) AB of the CC-especially the latter-opened the gate toward such an interpretation, based on which the protection of human rights and human dignity under the media regulations also stems from the institutional protection obligation of the state.

The protection of human dignity is one of the negative obligations (i.e. it obliges restraint, in other words, avoidance of infringements), which-similarly to certain positive obligations-through the institutional protection of these rights, protects the appropriate functioning of a democratic public sphere and not the individuals potentially violated in their rights. Because the main justification of rules appearing as restrictions on the freedom of the press is the protection of the viewer/listener/reader (collectively: the audience), "entitled" to such protection as a member of society and those common interests that are connected to the general recognition and respect of human rights. When media regulations prohibit the violation of human dignity, it protects with this fundamental principle of European civilization, that is, it excludes from democratic publicity that content which channels the lack of recognition of the respect, appreciation and equal status to which the individual is entitled.

Human dignity is a fundamental value, the prevalence of which permeates the entirety of the legal system and every venue of public life and so the media as well. This is a lot more than the protection of the personality of people violated in their rights, because the respect of this basic value is one of the principal foundations of public life and cooperation. 
(According to the Constitutional Court's view, the television and radio programs can seriously compromise this foundation, while press products cannot.)

The individual protection of human dignity in the media regulations is also justified by the special functions and characteristics of the media. This is because the media not only "turn up the volume" of specific opinions and communications (and by this, offensive content become "more dangerous"), but also-to a degree hard to measure-influence the audience; that is to say, they shape the level of demand, taste and culture of society. The role of the media is also symbolic: the media as a system symbolize the democratic system and, as the most important domain for social publicity, provide a picture of the functioning of society as a whole. As such, the limitations set for the media are in part also symbolic: they provide a picture of which values the legislature finds desirable to protect, even against those arguments in favor of no restrictions on public debate.

The Constitutional Court's jurisprudence drives enforcement toward this interpretation. According to Decision No. 46/2007 (VI. 27) AB,

[t]he NRTC in the course of the administrative proceedings is entitled to establish whether the broadcaster carries out its activities while respecting human rights, and whether the subject-matter, nature and perspective of its individual programs violate fundamental values embodied in human rights.

It follows from this that, even if according to the Constitutional Court the violation of human rights can be established based not on the violation of the individual rights but on the "nature and perspective" of the program, we can talk about more than mere individual grievance, but the behavior "required" to establish the violation, which is more serious by comparison.

The reasoning of Decision No. 165/2011 (XII. 20) AB of the CC provides more straightforward reference points for an interpretation arguing in favor of the separation of institutional protection and protection of individual rights. The reasoning of the decision cited before finds that the authority does not act "in the protection of the side of the protected right relating to the individual," and then state that the media "is capable of bringing about destruction in the culture of respect for human rights, especially human dignity;" hence, the protection of culture may be the objective of the media regulation. After this, the reasoning makes it clear that "it is justified that the authority-within the scope touching the institutional content of these rights - ... has the ability to act against the violator." With respect to Article 14(2) of the Press Freedom Act, it provides that the special protection of persons in humiliating, exposed or defenseless situations is appropriate because it may seriously compromise "the prevalence of the substance of the institution of human dignity." (All quotes are from paragraph IV. 2.2.2. of the reasoning of the opinion.) From the quoted sections of the text, it becomes clear that, according to the 
Constitutional Court, the objective and justification of the regulation are the protection of the 'institutional content' in the interest of the community (and not the individual).

There is only one final order in appellate proceedings which considered this issue with a ruling that overturned the decision of the media authority. In a tabloid program from a commercial television station, a patient treated in a psychiatric ward was recorded on a hidden camera in a humiliating situation while he was tied to the bed. The decision of the authority [Decision No. 1825/2008 (X. 1) ORTT of the NRTC] sanctioned the media service provider for the violation of the patient's personality rights (right to one's likeness and right to self-determination, and through these, the violation of the patient's human dignity). Although the institutional content might also have been violated by the depiction of the person in a humiliating, exposed or defenseless situation, the decision clearly referred to the violation of individual rights. However, the Hungarian Supreme Court, which ultimately decided the case, stated in its opinion (Decision No. Kfv. III.37.554./2010/5) that

[the authority] may examine the violation of human rights in the context as to whether the subject, nature and perspective of the program at issue violate the fundamental values materializing in human rights. Although the right to the freedom of self-determination is part of the right to human dignity, the issue of whether the right to one's likeness or other personal rights of the person in the program was violated by the fact that the person did not consent to the broadcasting is an issue for the domain of civil law. As it is apparent from Article 75(3) of the Civil Code, personality rights may be also violated even if the concerned person has consented if it violates or compromises social values. When the defendant authority has the right to act for the protection of an interest protected by the Radio and Television Broadcasting Act or for enforcing respect for the constitutional ordermanifested primarily in fundamental human rights - the inquiry should focus on whether the public interest protected by the Radio and Television Broadcasting Act is violated or compromised, independent of the concerned person's consent. If this protected value is not violated but the personal rights and human dignity of the concerned person are violated by the fact that the program at issue was broadcasted without the consent of this person, then such a situation, in which legal violation occurred not because of the broadcasting of the program toward the audience but based on facts outside of the subject, nature and perspective of the program - of which the audience watching the program usually does not even know-a personal rights violation, violating the right to self-determination, may also be enforced before a civil court as a right belonging to the right to selfdetermination of the aggrieved person. It follows from this that the legal violation in itself does not provide a basis for media authority actionpursuant to Article 3(2) of the Radio and Television Broadcasting Act 
referring to Article 54(1) of the Constitution -, although this circumstance may be considered in the course of imposing sanctions in the case of the violation of an interest protected by the Radio and Television Broadcasting Act.

With this opinion, the Hungarian Supreme Court has defined for enforcement purposes the appropriate interpretation of the protection of human dignity under the media regulations. The negative obligations set forth in the Press Freedom Act-therefore also including the protection of human dignity-establish through the media such basic "rules of the game," the respect of which is a precondition for conducting the debate. At the same time, the community has an interest in knowing all positions, hence even strong, sometimes outrageous, offensive or disturbing opinions; the community may not be deprived of their communication-merely by referring to their previously mentioned nature-in other words, the freedom of the press and open public debate can only be restricted with reference to human dignity violations based on sufficiently serious grounds, proportionately and within an appropriately narrow scope.

\section{Right to Self-Determination-Separation of the Branches of the Law}

The media regulations may not restrict the individual's right to self-determination, and the media authority may not act in the defense of others'-individual-rights, irrespective of the fact as to whether or not the person concerned has turned to other available forums before. Regarding the adjudication of cases which were initiated as a result of circumstances that also qualify as a violation of individual rights, the media regulations also take into account the possibility of the initiation of other (criminal or civil court) actions, and the tribunals administering the law (the media authority and the courts) must distinguish the media regulations from these other procedures.

The primary objective of criminal law is to deter its citizens from committing crimes in the future using the instruments of the state's penal authority, while the objective of civil law is to provide, if a right has been violated, the injured party with appropriate remedies (for example, by compensation for damages); this justifies, for example, conducting simultaneous proceedings for the protection of the person. At the same time, no similarly strong arguments can be raised for creating the possibility of a third proceedings (that of the media authority) to protect the individual. This is because the media regulation primarily protects - through the institutional protection of human rights and human dignity - the audience and not the individual attacked in the media.

\section{E. Jurisprudence}


The media authority has a serious jurisprudence in the institutional protection of human dignity. According to our position, cases in which certain media service providers show victims who are exposed or defenseless, or in a helpless situation or victims of accidents or crimes [e.g. Decision No. 2637/2006 (XI. 29.) ORTT of the NRTC, in which case a media service provider showed victims seriously injured during the 20 August fireworks] may be regarded as acting for the institutional protection of human dignity; this statement of facts is set forth with special emphasis in the Press Freedom Act.

Institutional protection may be similarly invoked in connection with the protection of the appropriate level of physical and emotional development of minors. The protection of minors and the undisturbed fulfillment of their personality are common social objectives and interests, and, therefore, it may be justified in certain cases to invoke public interest legal enforcement in their cases; in other words, the institutional protection of dignity may be necessary. The instance of a program showing the humiliation of a boy by his peers in the news from a media service provider [Decision No. 952/2009 (IV. 29) ORTT of the NRTC] or the interview made with a child who murdered her foster parent [Decision No. 736/2003 (V. 29) ORTT of the NRTC] could serve as relevant examples. In these situations we find authority action justified; not because it "substitutes" the theoretically existing but in practice limited individual legal remedy, but because in these actual situations we can discover institutional content violations. This is because the offences in these actual situations disregard and violate fundamental social norms and interests - the solidarity of the community and the healthy development of minors.

Programs with a concept and nature which disregard the respect of dignity and are built on questioning the fundamental value of dignity and the "untouchability" of human personality are also capable of violating human dignity. In 2001, in the trailer for a program called "The Reporter Tamás Frei," aired on a commercial television channel, the following pitch was announced: "Be part of a risky adventure. Accompany Tamás Frei [the reporter] to Moscow! Hire the hit-man who, for one million dollars, would even kill the Hungarian prime minister, with him!" Decision No. 665/2001 (V. 16) ORTT of the NRTC found for the violation of human dignity, not because the personal rights of the prime minister were violated, but because the message of the program was "capable of generating a sense of fear by suggesting that a person who can be hired for money, crossing all obstacles, merely in the hope of financial gains, would commit a violent act resulting in the taking of a human life. The statement of the communication, evoking intense emotions in the viewers, uttered in the imperative in a form that violated human dignity, is unacceptable."

The proceedings initiated in connection with the program called "The Price of the Truth" are an important milestone in the enforcement practice of the media authority, because they introduced a new rule of interpretation. The NRTC found for violation in that case, because the program suggested that human personality does not have untouchable realms 
and human dignity may be made public and accessible to anybody for financial gain [Decision No. 748/2008 (IV. 29) ORTT of the NRTC].

The new media authority, the Media Council (established in 2010 by the new regulation), followed the tracks of "The Price of the Truth" case. The tribunal found that a reality show ("Alekosz Is Looking for a Wife") violated human dignity and, with its 2011 decision, sanctioned the given large commercial media service provider for "objectifying" the participants, humiliating them in their femininity, deceiving them and making their private sphere public, as well as suggesting that human personality has no untouchable realms and that one can surrender the inviolability of human dignity for financial gains [Decision No. 1044/2011 (VII. 19)]. According to the authority, neither the participants' consent nor the extent of limitation of the utilization of legal means related to the protection of their personality as a result of their consent changes the fact of violation.

Furthermore, media content that questions the equality, unrestrictability and irrevocability of human dignity, which prevails with respect to every individual and social group, may be also regarded as the violation of human dignity. Based on the 2011 decisions of the Media Council, offensive opinions articulated against the Roma minority which disregard the value of human dignity, to which everybody is equally entitled, shall be considered unlawful [Decision No. 828/2011 (VI. 22) and Decision No. 1153/2011 (IX. 1)]. Based on the jurisprudence, specific media content which violates human dignity may in part be typified.

The following instances may be regarded as such:

- Explicit, recognizable and offensive depiction of persons in exposed or defenseless, helpless, or humiliating situations-e.g. victims of accidents or crimes-(in their cases the enforcement of rights is inherently limited, and showing people in these situations violates the rules of social coexistence too);

- The showing of minors in activities which violate human dignity or which necessitate institutional protection; individual enforcement of rights is limited in their cases too and the appropriate development of the personality of minors is also a common social interest, and action against content threatening that is justifiable (it should be noted that Article 19(4a) of the Press Freedom Act, effective as of 19 June 2012, supplements this situation and formulates the prohibition of showing minor persons in an offensive manner directly in the media content; the aim of the amendment was quite clearly to provide media law sanctions for such content appearing in press products too, despite the amendments that became necessary as a result of Decision No. 165/2011 (XII. 20) $A B)$;

- Treatment of certain persons or social groups as second class compared with others, as well as questioning their equal human dignity and the existence of their personal rights (the distinction between these cases and the manifestation of the circumstances contained in Article 17(2) of the Press Freedom Act-the prohibition of exclusion - can be a difficult task for the courts or the authority); 
- When the content of a media service suggests that human personality does not have untouchable realms, human life can be taken for money and human dignity for financial gain may be made public and accessible to anybody.

\section{F. "The Price of the Truth" case}

Decision No. 748/2008 (IV. 29) ORTT of the NRTC received broader-professionalpublicity, considering that it introduced a new type of interpretation in the authority's analysis of human dignity (human rights), ${ }^{13}$ so it is worth taking a closer look at the case.

"The Price of the Truth" was a game show and, before the studio recording, the players participated in a polygraph lie detector test, responding to certain different (in part innocent, in part embarrassingly personal) questions. When later, during the recording, they were asked some of the same questions, it was revealed immediately after they responded whether the earlier lie detector test had accepted their answer as true or false.

The authority's investigation of the 5 March 2008 episode found, among other things, the following:

[T] $\mathrm{T}$ e first round of questions is less uncomfortable for the players; in this case they related to the lady's appearance or perhaps hypothetical situations ("Can you look into the mirror in the morning without make-up? Do you prefer if your intellect is complemented and not your cleavage? Would you be willing to engage in cannibalism in order to stay alive?") The above questions-according to our opinion-contributed to revealing the side of the player's personality, which after commercial break could be followed by a group of questions-becoming more and more embarrassing as the amount of the prize increased-organized primarily around the subject of sexuality. It should be noted that the footage closing the segment already projected the failure of the player, and the viewers could witness the player's breakdown. They could see as the sobbing player's girlfriends escort her out (22:20:24), and they could also hear one of them telling the cameraman "Stop recording this!"(22:20:28).

In the second segment of the program, the player had to answer-among others-the following questions:

\footnotetext{
13 László Majtényi, Az ORTT szabadságjog-védelmi szerepe, (The NRTC's Role in Protecting Freedom Rights), 2 FUNDAMENTUM 102 (2010); Gábor Polyák, A Legfelsőbb Bíróság itélete Az igazság ára címü televíziós müsorszámról (The judgement of the Supreme Court regarding the television program entitled the "Price of the Truth"), 2 JOGESETEK MAGYARÁZATA 35 (2011).
} 
- (22:30:01) "Have you ever been disgusted by yourself? The answer: 'yes'."

- (22:31:56) "Do you have a breast implant? The answer: 'yes'."

- (22:34:38) "Do you also sleep with the musicians? The answer: 'yes'."

- (22:35:31) "Have you had sex with more than one man simultaneously? The answer: 'yes'."

After the player reached the one million-forint limit, the host asked the player the question: "Do you want more money?" The player said yes. The host, noticing the player became uncertain, thought he should stress the rules of the game in front of the cameras, too.

(22:37:26)

Player: "I don't think that there are more embarrassing questions than this. Although it is hard to embarrass me. It is not the questions I'm afraid of." Host: "The question is whether you lied during the test."

$\mathrm{P}$ : "No, but these are emotional questions and they are not necessarily yes or no questions, and in addition not all."

$\mathrm{H}$ : "But there is a result that is objective."

P: "Sure."

H: "So, you cannot."

The host motions with his hand that it is not questionable.

P: "Sure, of course. It is just hard, it is just hard to answer them, not to evaluate them, obviously. For me to decide, so that ..."

$\mathrm{H}$ : "This is why you can win so much money. You know that you can lose this one million forints if you gave a false answer even once?"

P: "Yes."

Question 16 concerned the sexual habits of the player again, but this time the host wanted to learn more.

(22:39:26)

H: "Have you ever been tied up during sex? The answer: yes."

P: "Don't look at me like this! What do you want to know? I do not want technical details."

$\mathrm{H}$ : "In short, everything."

P: "I thought so. But if I'm correct, this is a PG rated programme. I wouldn't get into it, I don't know what to say. I am like this."

$\mathrm{H}$ : "Did it leave a mark?"

P: "No, on the tattoo."

After this, they start talking about the meaning of the player's tattoo, which reveals the title of one of Almodóvar's movies, Tie Me Up, Tie Me Down.

Question 17, the last question:

(22:40:59)

H: "Have you ever been paid for sex?" The answer: 'no'. The answer is false," sounded the verdict. The player did not want to believe it, and her friends were also incredulous in the background.

$P$ : "This cannot be, you also know that this cannot be," turning to her friends. 
A relative of the player: "This is stupid!"

$P$ : "No."

$H:$ "This is what the polygraph showed."

$P$ : "I know, I know that I cannot question this, but this is probably such an embarrassing question in itself that when you hear it, and you are also nervous, that why would the person asking the question assume this?"

$\mathrm{H}$ : "Unfortunately, you answered 16 questions, I am very sorry, but thank you very much for being here."

The player was standing for a while at the edge of the stage, puzzled. She did not want to believe that the game really ended like that. Her friend waved, then she was told to go off the stage, and she left the set. The next footage showed the player sobbing in the arms of her friend, as her friend, embracing her, was trying to comfort the devastated girl. The camera was continuously following the player, and we could witness, as her friends went up to her and escorted out their sobbing friend.

The viewers could barely come to their senses from the details of the dramatic breakdown of the first player, and the next player was already up, who in the next minutes had to face-in the midst of the great amusement of the audience-no less embarrassing questions.

In the statement of reasons for the decision, the NRTC found that the game show

conveys that human personality has no integral, untouchable realms, and that human beings can be transparently humiliated, The program's participants sign up to reveal the innermost circles of their private lives for a monetary prize, and thus, the program carries the message that privacy and human dignity are not inviolable and. for material interest, they can be made public and consumable.

The operative part of the decision suspended the broadcasting license of the television media service provider for 30 minutes.

This interpretation is in line with the necessary separation of individual rights and institutional protection, and it provides the "abstract" interpretation of human dignity with a new meaning (i.e. that it can be and should be distinguished from violations of individual rights). The need for institutional protection can be established in connection with content conveying such messages because these programs question the fundamental value of human dignity, and with this, they indirectly challenge the democratic rule of law.

The opinion of the Hungarian Supreme Court, reviewing the decision of the authority (case no. Kfv. III.37.915/2009/6), analyses in detail whether any unavoidable personal rights violations occurred in the programme. With this respect the opinion makes it clear that 
the essence of the "game" is that the player in the given situation considers - when the question is asked-whether they wish to respond. This decision involves the player's actual consent concerning the revelation of a private secret to the public. If the player tells the truth, with that, they give their consent, but if they do not reveal their private secret the general consent given earlier cannot be regarded as consent either, because the player has withdrawn it. It follows from this that when, according to the host, the answer is false there are two possible scenarios. Either the player lied indeed, and in this case the revelation of the real information takes place against the will of the player, violating their right to informational selfdetermination, or the polygraph was wrong. In the latter case, the program conveys false information to the viewers about the person concerned which, being their innermost private secret, means the violation of their right to reputation. In these instances, therefore, it is logically impossible to prevent the violation of the right to reputation.

The reasoning of both the NRTC and the Supreme Court are acceptable, according to which there was no "'escape route" for human dignity in the program. They either reveal their innermost secrets or they try to keep them secret but, in this case, the lie detector will indirectly reveal them. The decisions of the authority and the court agreed that the violation of personal rights was unavoidable in the program.

According to the Supreme Court-in accordance with the holding of the authority's decision-the violation of dignity was realized by the "message" of the program. The reasoning of the Supreme Court's opinion cites in agreement the 2007 opinion of the Constitutional Court and the declaration of the media service provider plaintiff, according to which (quote from the Supreme Court's opinion):

[the examination of the violation of human rights and human dignity] does not mean the examination of the individual violations of the rights of the specific legal entities but the examination of whether the subject, nature and perspective of the programme violated the fundamental values manifesting in human rights. . . . The Hungarian Supreme Court adopted the starting point of the Constitutional Court, and thus that of the plaintiff, that the decision of the defendant [authority] established the violation of the first clause of Article 3(2) of the Radio and Television Broadcasting Act based not on violations of individual rights but based on the subject, nature and perspective of the programme.

According to our position, for the establishment of the violation of dignity under the media regulations, the occurrence of the violation of individual (personal) rights is not necessary. Decision No. 721/2010 (XII. 8) of the Media Council states this clearly: "media authority 
proceedings initiated for the examination of specific violations of personal rights and the violations of the provisions contained in Article 3(2) of the Radio and Television Broadcasting Act are distinct from each other; in other words, the violation of this provision may also be established even if there is no pending litigation before a court in connection with the violation of personal rights-for any reasons (e.g. the consent of the person concerned to the broadcasting of the program or failure to file a complaint) or even if the court found that no violation of personal rights had taken place". At the same time, it can be an important factor for the establishment of the violation if the violation of individual rights in the program is unavoidable. This is because it can serve as a good reason for the suspicion that the violation of dignity has occurred. As such, the necessary violation of individual rights may indicate that the violation of dignity under the media regulations has occurred, but it is by no means the condition, in a general sense, for establishing the latter.

\section{G. The Cohn-Bendit and Lomnici cases}

One of the segments of the program on channel m1 of Magyar Televizió (Hungarian Television) entitled Híradó (News), broadcasted on 1 April 2011, featured a report on the press conference in connection with Hungary's draft constitution by Daniel Cohn-Bendit, the representative of the European Green Party. From the report it appeared that CohnBendit refused to answer a question regarding earlier pedophilia allegations he was accused of and fled the press conference. The Media Council-despite viewer complaintsdid not initiate administrative proceedings for alleged violations of human dignity. In one of the segments of the news program entitled Híradó broadcasted on Duna Televizió (Danube Television) on 3 December 2011, and on the same day on channel $m 1$ of Hungarian Television, the face of Zoltán Lomnici, former President of the Hungarian Supreme Court was pixilated, as a result of which viewers were unaware that he attended the event which was reported in the story. The Media Council did not initiate administrative proceedings for the violation of human dignity in this case either.

Based on the decision of the authority, no institutional violation of human dignity took place in the Cohn-Bendit and Lomnici cases. It can be stated in general that false reporting about important events diminishes the faith in the reputation of the media and especially in the ethos of public service media. False reporting also restricts the viewers' right to adequate information and raises the issue of violation of the personal rights of the individuals concerned. However, it does not in itself violate human dignity protected under the media regulations. Although the viewers' right to information is violated if they see something on the screen that is different to what actually happened, the "message" of the program affected by this fact however does not necessarily transmit such content, which would then amount to the gravity of dignity violation. 
The Cohn-Bendit case appeared in the context of a major public (political) debate, which inherently requires a different approach from the authority applying the law as the assessment of content destroying the culture of human dignity. This is because, in political debates, the freedom of the press has a broader scope of latitude. In the case of political events (in the present case, the editing of a press conference is considered as such), Article 14 of the Press Freedom Act can only be applied in a very narrow scope.

On the other hand, the Lomnici case raises different types of issues. This is because, in a political sense, the former chief judge is clearly a neutral public figure, and, therefore, we cannot suspect there to be, behind the pixilation of Mr. Lomnici in the footage, an intention to express political or public opinion. (According to news bites, there were personal reasons behind the pixilation. At the same time, the blatant manner in which the manipulation was carried out raises the suspicion of provocation, but both "rumours" remained unconfirmed). As such, Mr. Lomnici, the former chief judge's right to reputation might have been violated, because the audience did not receive-indirect-information about his participation in a public event. Following the outbreak of the scandal, this generated the impression that he was some sort of a persona non grata in public life, who is not worthy to appear on television. (The story is qualified by the fact that, before and also after the incriminating report, he was invited on several occasions by public media outlets, so it is difficult to see any tendencies behind his one-time pixilation. However, an offence can be committed by one-time conduct, too. Nonetheless, it is important to point out that the gain obtained in the "marketplace of opinions" by the pixilation is not really visible; in other words, this editorial action could only influence public visibility to a small extent).

Naturally, falsification is unacceptable, even in connection with the highly protected expression of political opinion. The violation of the reputation or integrity of the persons concerned in these cases could have been taken place, but the violation of human dignity-especially, in the above analyzed "institutional" sense-according to the authority's decision, requires more severe conduct. What is certain, however, is that if we accept that the violation of any human or personal rights stemming from human dignity is sufficient for there to be a violation of human dignity, we would significantly devalue the concept of human dignity itself.

Of course, it is not impossible to imagine a violation of an individual right of such gravity that it would invoke the need for the institutional protection of dignity. In this case the offensive content is "separated" from the victims who suffered the specific violation, and the conduct would violate the respect (or, according to the 2011 opinion of the Constitutional Court, the "culture") of human dignity. However, a false statement published in the media (even if it is broadcasted by visual means), does not necessarily result in the violation of dignity. 


\section{H. Conclusion}

The protection of human dignity under the media regulations is an issue not completely resolved. The interpretation outlined in the present study-based on the jurisprudence of the Constitutional Court and other courts, as well as the authority-wished to provide a coherent content for the provision at issue, a content that respects the freedom of the press as well as the perspective of the separation of different areas of the law. Human dignity is today a "fashionable" legal concept and frequently serves as a basis of reference. However, several aspects of the concept still require further analyses. The need for appropriate interpretation is amplified by the nature of the content of profit-oriented media outlets, which often deny or neglect the principle of human dignity. As is apparent from the decisions of the authority and their reception, in the light of this issue, the legal analysis of content in connection with or published in the context of political questions is controversial. Although regulation or enforcement cannot provide completely satisfying and effective answers to these problems, they can significantly contribute to the resolution of them. 